\title{
Grandmother's Health Promotion Self-Efficacy Towards Postpartum Mother's Atitude In Exclusive Breastfeeding In The Working Area Of Sumobito Health Center Regency Of Jombang
}

\author{
Ririn Probowati ${ }^{1}$, Oktavia Indah Lesmana Dewi ${ }^{2}$, Heri wibowo ${ }^{3}$, mamik ratnawati ${ }^{4}$ Abdul \\ Muhith ${ }^{5}$ \\ \{abdulmuhith@unusa.ac.id, ririn_probowati@yahoo.com \} \\ 1,2,3,4,Nurses Profession STIKES, Jombang Regency Government, \\ ${ }^{2}$ Nursing science Department - University of Nahdlatul Ulama Surabaya (UNUSA)
}

\begin{abstract}
The small role of grandmother in exclusive breastfeeding is caused by the feeling that she is unsure that she can provide advice and motivation to the mother to giving an exclusive breastfeeding. The purpose of the study was to analyze the effect of grandmother's health promotion self-efficacy on postpartum mothers' attitudes in exclusive breastfeeding in the working area of Sumobito Health Center in Jombang Regency. The first step of the research design was a pre-experimental one-group pre-and post-test. The population of grandmothers with postpartum mothers who are breastfeeding infants aged 0-6 months is 40 . The number of samples, 36, was obtained through simple Random Sampling. With health promotion as the independent variable and grandmothers' selfefficacy as the dependent variable. The data analysis is using the Wilcoxon Signed Ranks Test with the value of $\mathrm{p}<0,05$. The second step was the dependant variable is grandmother's self-efficacy, the dependent variable is mother's attitude, using the Chi-Square test $\mathrm{p}$ value $<0.05$. The result of the first step was almost half $(36,1 \%)$ grandmothers' self-efficacy were in low category before being given health promotion. After being given health promotion, with a module, most of them $(52,8 \%)$ are in high category of grandmothers' selfefficacy. Using wilcoxon signed $\mathrm{p}=0,014$ test, there is an effect of health promotion on Grandmother's self-efficacy. On the second step, most of postpartum mothers $(55,6 \%)$ were in a high category for exclusive breastfeeding. Using Chi-Square test $\mathrm{p}=0,000$ test with closeness 0,521 , there is a high category connection between grandmother's self-efficacy and mother's attitude. The way to increase self-efficacy can be done by verbal persuasion,which is the provision of health promotion by referring to a module that grandmothers can study when they are home. Factors that can change the attitude of mothers are support from grandmothers who are role models for mothers in providing exclusive breastfeeding.
\end{abstract}

Keywords: health promotion, grandmother's self-efficacy, mother's attitude, exclusive breastfeeding 


\section{Introduction}

Health promotion is a combination of health education and interventions related to the economy, politics, and organization, which is designed to facilitate changes in conducive behavior and environment for health. ${ }^{1,2}$ Health promotion can be used as an influence on someone to behave to support his health. For nursing mothers, the grandmother acts as the most important source of support for new mothers or mothers who give birth for the first time. The experience of breastfeeding and the knowledge of the grandmother can influence the mother's decision to give and continue breastfeeding ${ }^{3}$. The greater support is obtained to continue breastfeeding, the greater the ability to be able to continue to breastfeed ${ }^{4}$. Grandmothers could give a negative and positive influence in breastfeeding. The positive influence is when grandmothers teach mothers how to breastfeed so that the mother is able to practice breastfeeding. However, the grandmother can also negatively affect the mother from the duration and exclusivity of breastfeeding because she tends to suggest giving extra fluids or providing complementary feeding to babies in the first months of life ${ }^{5}$.

Based on the result of research conducted by Wahyuni \& Rezkiki (2017) ${ }^{6}$ shows that structured health education proves an increase in self-confidence to make changes in behavior. The study proves that there is an increase score in self-efficacy in the group given educational intervention compared to the group that did health education control both before and after patients were treated three times. In addition, based on research of Nugroho et al. $(2017)^{7}$ it was found that the role of grandmothers in exclusive breastfeeding affects postpartum mothers as support from the closest people. Based on Probowati's research $(2016)^{8}$ the involvement and assessment of competencies in working mothers directly, which is verbal persuasion, affects a person verbally through education with modules as guidelines to improve maternal self-efficacy.

The data from 2016 in exclusive breastfeeding for infants younger than 6 months was $54.0 \%$ and had reached the 2016 strategic plan target of $42 \%$. By province, exclusive breastfeeding coverage for infants aged $0-5$ months ranged from $32.3 \%$ (Gorontalo) to $79.9 \%$ (East Nusa Tenggara). From 34 provinces only three provinces have not reached the target namely Gorontalo, Riau and Central Kalimantan ${ }^{9}$.

Research of Nugroho $(2017)^{6}$ states that support from families for mothers giving exclusive breastfeeding is still low. The role of the family around the mother, especially the grandmother, has a very large role in the success of exclusive breastfeeding. The role of grandmothers who already have breastfeeding experience is more dominant towards mothers when breastfeeding. Over the past 5 years, starting from 2010-2015, the Jombang district's achievement of exclusive breastfeeding has increased in 2015, whereas in 2016 there was a decline from 2015. (Jombang District Health Office Nutrition Section, 2017) ${ }^{10}$.

\section{Research Methods}

The first phase of research is pre-experimental with a pre-and post-test approach in one group (one group pre- and post-test design). The population is all grandmothers who have children breastfeeding infants aged 0-6 months in the working area of Sumobito Health Center is 40 in December 2018 to March 2019. The sampling technique used was simple random sampling, there are 36 samples. The independent variable is health promotion based on a 
module given to grandmother whilst the dependent variable is grandmother's self-efficacy. Wilcoxon statistical test with a significant level of 0.05 . Data collection techniques used were four visits with sequences in one visit, which are pre-test, intervention and post-test. The second phase is cross sectional design. The population is all mothers who are breastfeeding infants aged 0-6 months. The sampling technique used is simple random sampling, there are 36 samples. The independent variable is grandmother's self-efficacy and the dependent variable is the mother's attitude in exclusive breastfeeding with the Chi-Square test with a significant level of 0.05 .

\section{Research Results}

The first phase on grandmother's self-efficacy before and after given a health promotion.

Table 1.Grandmother's General Data Frequency Distribution

\begin{tabular}{|c|c|c|}
\hline General Data & & $\%$ \\
\hline \multicolumn{3}{|l|}{ 1. Grandmother's Age } \\
\hline $36-45$ years old & 7 & 19,4 \\
\hline $46-55$ years old & 15 & 41,7 \\
\hline $56-65$ years old & 14 & 38,9 \\
\hline \multicolumn{3}{|l|}{ Education } \\
\hline Education & 26 & 72,2 \\
\hline Middle Education & 10 & 27,8 \\
\hline \multicolumn{3}{|l|}{ Profession } \\
\hline Entrepreneur & 5 & 13,9 \\
\hline Private & 1 & 2,8 \\
\hline Housewife & 30 & 83,3 \\
\hline \multicolumn{3}{|l|}{ Number of Grandchildren } \\
\hline $1-2$ & 24 & 66.7 \\
\hline $3-4$ & 10 & 27.8 \\
\hline$>5$ & 2 & 5.6 \\
\hline
\end{tabular}

Table 1 shows that almost half of them (41,7\%), 15 respondents are aged $46-55$ years old. It shows that almost half $(72,2 \%), 26$ respondents' education, were low. It shows that almost all $(83,3 \%), 30$ respondents' profession, is housewife. It also shows that most of them $(66,7 \%), 24$ respondents, are taking care of 1-2 grandchildren.

According to Bandura (1997) ${ }^{11}$, each individual has a different self-efficacy. Experience is something that determines the self-confidence. The older individuals will have more experience in their lives than younger individuals. Bandura (1997) explains that individuals who have a higher level of education usually have high self-efficacy, because they learn more and receive a more formal education, and get more opportunities to learn in dealing with problems in their lives ${ }^{11}$.

Based on the research (Probowati, 2017) ${ }^{8}$ someone's profession can be associated with the working environment. People who work in offices or a company will have a variety of friends' characters with different kinds of self-efficacy backgrounds, so they can exchange information with other friends. On the contrary, respondents whose daily lives consist of staying at home could not information with people who have better self-efficacy than themselves ${ }^{8}$. 
Table 2. The frequency distribution of grandma's self-efficacy before and after being given a health promotion

\begin{tabular}{llllll}
\hline No & Grandmother's Self efficacfy & \multicolumn{2}{l}{ Before } & \multicolumn{2}{l}{ After } \\
& & $\mathrm{f}$ & $\%$ & $\mathrm{~F}$ & $\%$ \\
1 & High & 13 & 36,1 & 19 & 52,8 \\
2 & Low & 23 & 63,9 & 17 & 47,2 \\
& Total & 36 & 100 & 36 & 100 \\
\hline
\end{tabular}

Table 2 shows that before being given health promotion most $(63,9 \%)$ mothers have low self-efficacy, 23 respondents, after being given intervention in the form of health promotion almost half $(47,2 \%)$ mothers with low self-efficacy, 17 respondents, which means that low self-efficacy has decreased by $16,7 \%$.

Self-efficacy is a positive indicator of self-evaluation which is useful for understanding yourself. The high and low of someone's self-efficacy varies greatly and is influenced by several factors including gender, age, education level, and experience. ${ }^{8]}$ The health promotion interventions can increase mothers' self-efficacy from a low category $(10 \%)$ to a better one $(90,0 \%)$. Health promotion which is guided by a module can be used as a self-study at home if grandmother feels there is something that needs to be learned. The verbal persuasion conducted over four times in a month gives grandmother the opportunity to discuss about exclusive breastfeeding after getting a health promotion, thus the grandmother's confidence will increase.

The Wilcoxon test results, with $\mathrm{p}$ value of grandmother's self-efficacy is 0.014 , there is an effect of health promotion on grandmother's self-efficacy. By using a health promotion module, it can increase grandmother's self-efficacy in exclusive breastfeeding for infants aged 0-6 months. According to Bandura (1997) ${ }^{11}$ self-efficacy can be grown and studied through four main sources which are the experience of success, other people's experiences, verbal persuasion, and physiological conditions. Using health promotion researchers believe that they can increase grandmothers' self-efficacy to postpartum mothers on exclusive breastfeeding infants aged 0-6 months. Researchers also facilitate respondents with learning modules that can be used as guidelines for grandmothers and mothers to learn at home to make it easier to understand and learn about the importance of exclusive breastfeeding in infants aged 0-6 months.

Health Promotion merupakan aspek dari persuasi verbal, dimana individu diarahkan dengan saran, nasihat, dan bimbingan sehingga dapat meningkatkan keyakianan tentang kemampuan diri yang dimiliki untuk mencapai tujuan yang diinginkan. Health Promotion secara verbal dengan sebuah modul merupakan model pembelajaran yang dapat mempermudah nenek dalam memahami dan mempelajari hal-hal yang belum diketahui sebelumnya tentang Pentingnya pemberian ASI esklusif pada bayi usia 0-6 bulan. ${ }^{11}$. Modul yang di bawa pulang dapat di gunakan oleh nenek sesuai kebutuhan nya. Penggunan modul untuk meningkatkan self-efficacy sebelumnya di jelaskan oleh peneliti . Pendmapingan selama 1 bulan dalan enggunaan modul dlakukan dengan mendatangi setiap satu minggu seklai selama 1 bulan, rata-rata nenek sudah dapat memahami tetang pemberian ASI ekslusif.

The second phase of the connection between grandmother's self-efficacy and mother's attitude in exclusive breastfeeding in infants aged 0-6 months 
Table 3. Mother's General Data from Frequency Distribution

\begin{tabular}{|c|c|c|c|}
\hline No & General Data & $\mathrm{f}$ & $\%$ \\
\hline \multicolumn{4}{|c|}{ 1. Mother's Age } \\
\hline & $<20$ years old & 7 & 19,4 \\
\hline & 20- 35 years old & 22 & 61,1 \\
\hline & $>35$ years old & 7 & 19.4 \\
\hline \multicolumn{4}{|c|}{ 2. Education } \\
\hline & Low Education & 20 & 55,6 \\
\hline & Middle Education & 14 & 38,9 \\
\hline & College & 2 & 5.6 \\
\hline \multicolumn{4}{|c|}{ 3. Profession } \\
\hline & Entrepreneur & 2 & 5.6 \\
\hline & Private & 1 & 2,8 \\
\hline & Housewife & 33 & 91.7 \\
\hline \multicolumn{4}{|c|}{ 4. Number of Children } \\
\hline & & 24 & 66.7 \\
\hline & & 10 & 27.8 \\
\hline & & 2 & 5.6 \\
\hline
\end{tabular}

Table 3 shows that most mothers $(61,1 \%)$ aged are $20-35$ years old. $55,6 \%$ of the respondents have low education and $66.7 \%$ have one to two children. The result of the connection between grandmother's self-efficacy with the mother's attitude in exclusive breastfeeding is Chi-Square Test $p=0,000$ with a closeness of 0.521 , which means there is a high closeness between the grandmother's self-efficacy with the mother's attitude in breastfeeding.

Attitude is a reaction or response of someone who is still closed to an object stimulus. Attitude clearly shows the suitability of certain reactions ${ }^{12}$. Attitude is still a closed reaction and not an open reaction. The formation of an attitude through a stimulus received, the stimulus can be rejected or accepted by individuals. The stimulus received means that there is individual attention and the stimulus is effective. Attitudes are influenced by age, education, and experience ${ }^{12}$. The mother's age in the reproductive age group is a group in which a woman can provide risk without risk. In this group mothers are required to be able to give birth and provide care to their babies properly, including in providing exclusive breastfeeding. Informal education obtained by a mother is a basic mindset of a mother. Higher education will make it easier for mothers to receive information related to exclusive breastfeeding which is the basis for mothers to have a good attitude in breastfeeding. The number of children is also an experience in providing care to their babies. A mother who has a baby for the first time will have a low attitude because she has no prior experience in breastfeeding. The mother's experience in providing baby care for breastfeeding will influence the attitude in exclusive breastfeeding.

Various factors that influence attitudes includes ${ }^{12}$, (1) Personal experience: A good personal experience will form a good attitude. The experience of a mother who has breastfed a baby before will influence the mother's attitude in caring for her baby now. The experience of a grandmother's success in giving breastfeeding to her child will be an example for mothers in giving breast milk. (2) The influence of culture: culture is very influential on the formation of attitudes. If we live in a culture that upholds religious values, a positive attitude will be formed (giving breast milk until the age of two years, culture giving breast milk in the neighborhood). 
(3) Mass Media: information conveyed through various means can shape a person in his attitude. an example is information about exclusive breastfeeding that is intensively given by health workers, print media and electrolytes and will form the attitude of mothers in giving exclusive breastfeeding.

Table 4. Cross Tabulation Between Grandmother's Self-efficacy and Mother's attitude in exclusive breastfeedin

\begin{tabular}{llll}
\hline Self-efficacy & \multicolumn{3}{c}{ Attitude } \\
& $\%)$ & o) & Total \\
\hline High & $.2 \%)$ & $\%)$ & $19(100 \%)$ \\
Low & $5 \%)$ & $5 \%)$ & $17(100 \%)$ \\
TotTotal & $5 \%)$ & $1 \%)$ & $36(100 \%)$ \\
\hline
\end{tabular}

Chi Square statistical test $\rho=0.000$ and closeness 0.521

The measurement of the mother's attitude is done after the grandmother received a health promotion regarding grandmother's self-efficacy in exclusive breastfeeding four times in one month.

In table 4 it shows that the grandmother's self-efficacy was mostly (84.2\%) high in mother's attitudes. If grandmother's self-efficacy is low, then the mother's attitude is also low. Grandmother's self-efficacy is strongly related to the mother's attitude in exclusive breastfeeding. Grandmother's self-efficacy is a belief held by grandmothers to motivate to their children (mothers who are breastfeeding), in order to have a high attitude in exclusive breastfeeding. Grandmother is a role model that must be listened to and accepted by all the talk and behavior for a mother. A child (a nursing mother) will use her mother (the baby's grandmother) as a role model in caring for her baby. A grandmother's experience in providing care for her baby while breastfeeding will make a strong basis for self-efficacy in providing guidance to her child in exclusive breastfeeding. For a mother, a grandmother is the closest person to provide care for her baby because the grandmother can help in giving care, can give direction, and guidance in giving care. Therefore, a grandmother will be able to provide this if she has high self-efficacy in providing exclusive breastfeeding.

\section{Conclusion}

1. Grandmother's high self-efficacy is strongly related to mother's high attitude in exclusive breastfeeding.

2. One way to improve grandmother's self-efficacy in exclusive breastfeeding is through health promotion using a module guide that can be learned by grandmothers when they are at home. 


\section{Reference}

[1] Martha Raile Alligoad, Nursing Teorist and their Work. By Mosby, 2014

[2] Grassley, J. S \& Eschiti, V. 2009. Grandmothers Breastfeeding Support : What Do Mothers Need and Want. http://www.ncbi.nlm.nih.gov/pubmed/19036046. Diakses pada 5 Januari 2019 pukul 10.00WIB.

[3] Anggrowati. 2013. Hubungan Antara Dukungan keluarga dengan Pemberian ASI Eksklusif pada bayi di Desa Bebengan Kecamatan Boja Kabupaten Kendal. http://jurnal.unimus.ac.id./index.php//JKMat/article/view/927.

[4] Susin, i, r, giugliani, e. r., dan kummer, s. c. 2005.influence of grandmothers on breastfeesing practice . http://www.ncbi.nlm.nih.gov.pubmed/15895130 (5 januari 2019).

[5] Wahyuni, A., \& Rezkiki, F. (2017). Pemberdayaan dan Efikasi Diri Pasien Penyakit Jantung Koroner melalui Edukasi Kesehatan Terstruktur. Jurnal Ipteks Terapan, 9(1).

[6] Nugroho, R., Waryana, W., \& Aritonang, I. (2017). Peran Nenek dalam Peningkatan Cakupan ASI Eksklusif di Desa Bangunjiwo Kasihan Bantul. JURNAL NUTRISIA, 19(1), 68-78.

[7] Probowati, Ririn. 2016. Model keperawatan Role attachment ibu bekerja dengan pendekatan selfefficacy dalam kompetensi stimulasi pertumbuhan dan perkembangan bayi. Disertasi. Program Studi Kesehatan Masyarakat Fakultas Kesehatan Masyarakat Universitas Airlangga : Surabaya.

[8] KEMENKES.2017.profil kesehatan RI. Jakarta. http://www.depkes.go.id/Profil-KesehatanIndonesia-tahun-2017.pdf

[9] Seksi Gizi Dinkes Kabupaten Jombang. 2017. Profil kesehatan tahun 2018. Jombang :Dinkes Kab. Jombang.

[10] Bandura, A. (1997). Self-efficacy in Changing Societi. New York: W.H.Freeman Notoatmodjo, S. (2010). Ilmu perilaku kesehatan (Vol. 200). Jakarta: Rineka Cipta.

[11] Muhith, A dkk (2019). Structural Equation Modeling: Community Empowerment on Health Status and Pregnant Women Nutritional. Journal of Engineering and Applied Sciences Volume 14 Issue: (7): Page No.2385-2392, (2019). ISSN: 1816-949X. DOI: 10.3923/jeasci.2019.2385.2392 http://medwelljournals.com/abstract/?doi=jeasci.2019.2385.2392

[12] Muhith, A., Lutfiana Wulandari, (2017). Family's economic level and culture correlate with nutritional status of children under five years, Jurnal Jurnal Ners, vol 9 no. 1, Halaman 138-142. Fakultas Keperawatan Universiatas Airlangga Surabaya, Doi = http://dx.doi.org/10.20473/jn.v9i1.3279 url: https://ejournal.unair.ac.id/JNERS/article/view/3279

[13] Muhith, A., (2017). A study about the quality of nursing services at hospitals' ward at mojokerto, Jurnal Jurnal Ners, vol 9 no. 2, Halaman 321-328. Fakultas Keperawatan Universiatas Airlangga Surabaya, Doi = http://dx.doi.org/10.20473/jn.V9I22014.321-328 url: https://ejournal.unair.ac.id/JNERS/article/view/2688

[14] Muhith, A. (2017). Pengembangan model mutu asuhan keperawatan dan MAKP. Yogyakarta: cv. Enterpreuner.

[15] Muhith, A., dkk (2016). Nursing Service Quality Model Based on Nursing Performance and Patient Satisfaction Analysis in Gresik District Hospital journal of health medicine and nursing, 23, ISSN 2422-8419 url: http://www.iiste.org/Journals/index.php/index/search/results

[16] Muhith, A. (2018). Aplikasi Comunication Terapeutic Nursing \& Health Yogyakarta: publihser CV.Andi.

url https://books.google.co.id/books?hl=en\&lr=\&id=fL9jDwAAQBAJ\&oi=fnd\&pg=PR5\&dq=info: yYZ5d6KCWPcJ:scholar.google.com\&ots=phcESQdDP0\&sig=jC-

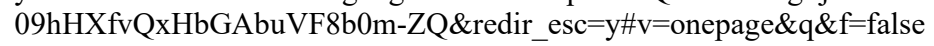

[17] Muhith A, dkk (2018). Relationship of Sleep Quality with Student Learning Motivation in Nursing Academy 17 of Karanganyar, Indian Journal of Public Health Research \& Development, Volume. 9 Number 12. First page Pages: 1410-1413. Published: Dec 2018 Print ISSN: 09760245 Online ISSN: 0976-5506 DOI: 10.5958/0976-5506.2018.02051.X, url: http://www.indianjournals.com/ijor.aspx?target=ijor:ijphrd\&volume=9\&issue=12\&article=255 